\title{
A vulnerabilidade externa decorrente da Posição Internacional de Investimentos e do fluxo de rendas da economia brasileira no período 2001-2010
}

External vulnerability due to the International Investment Position and the income flows in Brazil from 2001 to 2010

\author{
Paulo Van Noije \\ Universidade Estadual de Campinas \\ Bruno De Conti \\ Universidade Estadual de Campinas
}

\begin{abstract}
This article presents Brazil's external financial vulnerability resulting from foreign stocks (International Investment Position) and flows of income. It analyses the Brazilian economy during the period 2001-2010 and concludes that: i) the reduction of the stock-vulnerability of the Brazilian economy, as demonstrated during the global crisis beginning in 2008, was due to a new composition of the International Investment Position, and an increase in international reserves and external liabilities denominated in the domestic currency, and these tend to suffer a double devaluation (price and exchange rates) in times of crisis; ii) net income sent abroad in this period amounted to US\$273 billion, crystallizing the flow-vulnerability through dependence on external financing for the current account deficit; iii) variations in prices of external stocks is the most important variable in the changes of balances of the International Investment Position.
\end{abstract}

\section{Keywords}

International Investment Position; external vulnerability; balance of payments; current account; Brazilian economy.

JEL Codes E44; F34; F49.

\section{Resumo}

$O$ artigo apresenta a vulnerabilidade externa brasileira, baseada na esfera financeira, decorrente dos estoques externos (Posição Internacional de Investimentos) e dos fluxos de rendas. Analisa-se a economia brasileira no periodo 2001-2010 e chega-se às seguintes conclusões: i) houve diminuição da vulnerabilidade-estoque da economia nacional, conforme evidenciado na crise global eclodida em 2008, por conta de mudanças na Posição Internacional de Investimentos (PII), com o aumento das reservas internacionais e da participação do passivo externo denominado em moeda doméstica, que tende a sofrer dupla desvalorização (câmbio e preço) em momentos de crise; ii) as rendas líquidas enviadas ao exterior durante a década em questão atingiram o valor de US\$ 273 bilhões, cristalizando-se a vulnerabilidade-fluxo por meio da dependência dos financiamentos externos para equilibrar os déficits das transações correntes; iii) a variação de valor dos estoques externos é a variável mais importante nas alterações dos saldos da Posição Internacional de Investimentos.

\section{Palavras-chave}

Posição Internacional de Investimentos; vulnerabilidade externa; balanço de pagamentos; transações correntes; economia brasileira.

Códigos JEL E44; F34; F49. 


\section{Introdução}

O aprofundamento da integração econômica entre os distintos países do globo amplia a importância dos estudos relativos à vulnerabilidade externa. No entanto, a despeito de sua relevância, esse tema é muitas vezes abordado de forma parcial. A vulnerabilidade externa manifesta-se em esferas distintas - comercial, produtivo-tecnológica e monetário-financeira - e é importante que elas sejam todas contempladas. Contudo, as análises sobre o tema são geralmente focadas no comércio exterior, e muitos modelos de crise do balanço de pagamentos consideram as rendas líquidas enviadas ao exterior como nulas e acabam desconsiderando a questão patrimonial. Partindo da análise da esfera financeira, pretende-se neste artigo contribuir com os debates, explorando-se um aspecto geralmente negligenciado pela literatura, qual seja, a forma com que a composição dos estoques externos e sua interação com as rendas enviadas/recebidas do exterior influenciam a vulnerabilidade externa.

O artigo parte do arcabouço teórico que identifica em âmbito mundial um fenômeno de expressivo aumento dos fluxos de capitais, com crescente financeirização das transações externas (Aglietta, 2008; Chesnais, 2005; Belluzzo, 2006; Guttmann, 2008); e, no âmbito doméstico brasileiro, um processo de abertura da conta financeira que insere o país na globalização financeira (Carneiro, 2002; Oreiro; De Paula; Da Silva, 2003; Barbosa; Souza, 2010).

Ademais, considera-se importante, para a análise da vulnerabilidade externa, estudá-la dentro de um arcabouço que contemple a hierarquia do Sistema Monetário Internacional (SMI). O ponto relevante é que algumas moedas não conseguem desempenhar suas funções clássicas (unidade de conta, meio de pagamento e reserva de valor) em âmbito internacional. Isso ocorre com os países periféricos não em função de suas políticas internas, mas por fatores geopolíticos e geoeconômicos, que estruturalmente determinam essa hierarquia monetária. Ao fim, os países emissores de moedas periféricas têm geralmente maiores taxas de juros, dificuldades para obter financiamento de longo prazo e incapacidade de se endividar na própria moeda no mercado internacional (Prates, 2002; Carneiro, 2008; De Conti, 2011).

Partindo desse arcabouço, Biancarelli (2010) aponta que a alocação da riqueza internacional em ativos de países periféricos ocorre apenas 
em momentos de baixa preferência pela liquidez e de busca por maiores rentabilidades, ou seja, de baixa aversão ao risco no plano internacional, que acabam configurando o momento de "cheia" dos ciclos de liquidez internacional (aumento de liquidez para os periféricos). ${ }^{1}$ A reversão das expectativas, porém, engendra uma realocação das posições dos agentes globais e intensa retirada de capital desses mercados. Dessa maneira, esses momentos de "cheia" e de "seca" são muito mais condicionados por fatores externos do que internos aos países periféricos. Nota-se, então, que a capacidade dos países periféricos de interferirem na oferta voluntária de divisas disponível para suas economias é relativa, em função da estrutura hierarquizada do SMI.

Já os países cujas moedas estão no núcleo do SMI (as moedas centrais) conseguem manter uma taxa de juros menor do que os periféricos sem gerar fuga de capital, tendo, portanto, maior margem de manobra para o exercício de sua política econômica - fenômeno chamado por Prates (2002) de "assimetria macroeconômica". Diante desse quadro, parece evidente que os países de moeda central tendem a apresentar menor vulnerabilidade externa, ao passo que os periféricos são mais suscetíveis às variações na oferta de divisas, decorrentes das distintas etapas dos ciclos de liquidez internacional.

Dentro desse contexto de globalização financeira e hierarquia monetária e com a continuidade do processo de liberalização financeira no Brasil, os anos 2000 foram marcados por expressiva entrada de capitais com perfil especulativo no país, resultando em grande aumento do passivo externo líquido, o que sugere piora da vulnerabilidade externa da economia brasileira. Entretanto, o governo brasileiro pôde responder à eclosão da crise internacional recente adotando medidas monetárias e fiscais anticíclicas, possibilitando uma recuperação relativamente rápida da economia doméstica - ao menos nos anos imediatamente posteriores à eclosão da crise. Tal fato sugere o oposto, ou seja, melhora na situação da vulnerabilidade externa brasileira.

Esse aparente paradoxo deve ser analisado pela ótica de uma importante transformação verificada nas contas externas nacionais, qual seja, a significativa mudança na Posição Internacional de Investimentos (PII) brasileira, com redução dos passivos externos denominados em moeda estrangeira e

1 Para detalhes sobre os ciclos de liquidez internacional, ver Biancarelli (2007). 
aumento da participação dos passivos externos denominados em moeda doméstica. Esse passivo de passivo - em real - tende a sofrer dupla desvalorização - câmbio e preço - em momentos de crise, de forma que a variação do valor dos estoques externos, nessa composição da PII, mostra-se benéfica para o país nos momentos de maiores dificuldades, caracterizando o que se chamará neste artigo de menor vulnerabilidade-estoque.

Assim, mesmo no momento de alteração do contexto internacional, em que uma situação de abundância de liquidez se modificou para uma de escassez, a ameaça de saída de capitais estrangeiros - quando os investidores externos decidem repatriar os recursos que constituem o passivo externo doméstico - acabou não se manifestando de forma tão intensa, permitindo maior raio de manobra para a política econômica doméstica durante o momento mais agudo da crise.

Entretanto, deve-se destacar também que a composição e a magnitude da PII afetam as remessas de rendas, sobretudo porque no Brasil, conforme se mostrará adiante, o retorno do ativo externo é muito menor que o do passivo externo, ou seja, formar reservas internacionais tem um custo muito elevado para o país.

A economia brasileira é estruturalmente deficitária em sua conta de rendas. Esses recursos enviados ao exterior originam permanente necessidade de geração de divisas, geralmente não satisfeita por superávits da balança comercial e de serviços, fazendo com que o país fique dependente do financiamento externo para fechar seu balanço de pagamentos; constitui-se, então, o que se chama aqui de uma vulnerabilidade-fluxo da economia brasileira, decorrente dessa circularidade entre estoques e fluxos, que faz com que a entrada dos capitais estrangeiros acabe servindo, em grande medida, para honrar os compromissos desses próprios estoques externos.

Em suma, pode-se considerar que a acumulação de um passivo externo líquido elevado significa o aumento da vulnerabilidade externa, ou seja, a diminuição do poder efetivo da política econômica e uma perda de sua autonomia. Mas que, além dessa análise quantitativa, também é necessária uma análise qualitativa dos estoques externos, pela apreciação de sua composição. Sobretudo, diante da constatação de que a dinâmica de evolução dos estoques externos passa a depender cada vez mais das mudanças de valor desses, já que essa variação adquire certa autonomia em relação aos saldos das transações correntes. Tal processo é gerado por dois fatores principais: a) pela própria variação do preço dos ativos; b) pelas variações 
cambiais, dentro de um contexto de descasamento de moedas entre os passivos e os ativos externos.

Partindo da perspectiva apresentada acima, o objetivo deste trabalho é analisar a vulnerabilidade externa decorrente da PII e do fluxo de rendas da economia brasileira no período 2001-2010. O recorte temporal justifica-se pela pertinência de um registro analítico detalhado sobre o setor externo brasileiro na primeira década do século XXI, mas também - e principalmente -, pois se trata de um período particularmente interessante, visto que marcado por uma fase de abundância de liquidez em âmbito internacional, interrompida pela maior crise do capitalismo desde 1929. No caso específico do Brasil, o período é particularmente instigante, uma vez que apresenta o paradoxo supramencionado, de um PII que cresce de maneira extraordinária, mas com manifestações imediatas menos nocivas dessa vulnerabilidade externa.

Além desta seção introdutória e das considerações finais, o artigo se organiza em mais duas seções. A próxima seção apresenta propostas metodológicas para a análise da Posição Internacional de Investimentos e da vulnerabilidade externa. Na seção 3, apresenta-se a evolução da PII brasileira ao longo do período 2001-2010 e das rendas enviadas e recebidas do exterior, que ajudarão na compreensão das mudanças na PII durante o período estudado e, portanto, da vulnerabilidade externa da economia brasileira.

\section{Posição Internacional de Investimentos e vulnerabi- lidade externa: questões metodológicas}

\subsection{Posição Internacional de Investimentos: estrutura e determi- nantes de sua evolução}

Apresenta-se abaixo o Quadro 1 referente à primeira estrutura da Posição Internacional de Investimentos (PII), que é igual à diferença entre os ativos e os passivos externos brutos de um país. O cálculo e a apresentação da PII seguem a metodologia da quinta edição do Manual do Balanço de Pagamentos do Fundo Monetário Internacional (Simonsen; Cysne, 2007). A categorização dos estoques de ativos e passivos na PII corresponde aos componentes da conta financeira do balanço de pagamentos (BP): investimento direto, investimento em portfólio, derivativos e outros investimentos. 


\begin{tabular}{l|l}
\hline (A) Ativo Externo Bruto & (B) Passivo Externo Bruto \\
\hline - Investimento direto no exterior & $\bullet$ Investimento direto estrangeiro \\
- Investimento em carteira & - Investimento em carteira \\
- Derivativos & - Derivativos \\
- Outros Investimentos & - Outros Investimentos \\
- Ativos de Reservas & \\
\hline
\end{tabular}

Fonte: Banco Central; elaboração própria.

O BP registra os fluxos entre o país e o exterior num determinado período contábil, ou seja, as transações efetivas entre residentes e não residentes da economia doméstica, geralmente em um ano. Já a PII complementa o BP, através do balanço de estoques. Seu objetivo é apresentar, a cada ponto no tempo, o total de ativos e passivos financeiros externos de uma economia (FMI, 1993).

Tradicionalmente, não se utiliza o termo Posição Internacional de Investimentos nas discussões sobre os estoques externos, sendo primordialmente empregado o termo Passivo Externo Líquido (PEL). Existem duas maneiras diferentes de se calcular o PEL:

a) PEL1: O Passivo Externo Líquido 1 é calculado como o déficit acumulado ao longo do tempo na conta-corrente do balanço de pagamentos; no caso brasileiro, tal valor é acumulado do início de 1947 em diante ${ }^{2}$ (Cysne, 2008). O PEL1 é, portanto, uma proxy do Passivo Externo Líquido, com a vantagem de facilitar os cálculos de sua elaboração.

b) PEL2: O Passivo Externo Líquido 2 é calculado como o estoque do passivo externo bruto menos o estoque do ativo externo, ou seja, o oposto da Posição Internacional de Investimentos, de forma que PII $=-$ PEL2 $^{3}$ (Cysne, 2008).

Para explicar os conceitos de Passivos Externos Líquidos (PEL1 e PEL2) e da Posição Internacional de Investimentos, serão utilizadas as seguintes igualdades:

$$
S T C_{t}=-S C F_{t}+\triangle R E S_{t}
$$

2 Ano de início da contabilização do balanço de pagamentos brasileiro pelo Banco Central do Brasil. Supõe-se, por simplificação, um Passivo Externo Líquido igual a zero no início de 1947 (Simonsen \& Cysne, 2007).

3 Dessa maneira, além de retratar, como o PEL1, o histórico das transações correntes do país, o PEL2 incorpora os efeitos das alterações de valor e de quantidade dos passivos e dos ativos externos. 


$$
\begin{aligned}
& \triangle P E L 1_{t}=-S T C_{t} \\
& -\sum_{i=1} S T C_{i}=P E L 1=D C C A \\
& P E L 2=P E L 1+V \\
& A_{e x t}-P_{e x t}=P I I=-P E L 2 \\
& P E L 2=P_{e x t}-A_{e x t}
\end{aligned}
$$

em que STC é o saldo em transações correntes, SCF é o saldo na conta financeira, RES são as reservas internacionais, PEL1 é o Passivo Externo Líquido 1, PEL2 é o Passivo Externo Líquido 2, DCCA é o déficit acumulado na conta-corrente do balanço de pagamentos, $A_{\text {ext }}$ é o estoque de ativos externos, $P_{\text {ext }}$ é o estoque de passivos externos, PII é a Posição Internacional de Investimentos, e $\mathrm{V}$ é o valor líquido das valorizações ou desvalorizações de ativos externos e passivos externos, monetizações ou desmonetizações de ouro e alocações ou cancelamentos de Direitos Especiais de Saque (DES).

Dessa maneira, identifica-se por (1) que o saldo em transações correntes é igual o oposto do saldo da conta financeira mais a variação das reservas internacionais, ou seja, um déficit em transações correntes no ano t, por exemplo, é financiado pela entrada de capitais pela conta financeira no ano t e/ou pela queda das reservas internacionais, gerando, conforme se observa em (2), um aumento do Passivo Externo Líquido 1 (PEL1) no ano t.

Um aspecto fundamental dessa análise é que os fluxos financeiros por si sós não alteram o saldo da PII. Por (2), percebe-se que apenas o saldo das transações correntes afeta o saldo da PEL1. Isso ocorre porque, como se nota em (1), se o saldo das transações correntes for igual a zero, a variação das reservas internacionais vai ser igual ao saldo da conta financeira, ou seja, a magnitude da mudança no ativo externo vai ser igual à do passivo externo, não alterando o saldo da PII.

Já por (3), o PEL1 pode ser entendido como o déficit acumulado na conta-corrente (DCCA) do balanço de pagamentos, isto é, pode-se perceber que o somatório (do oposto) dos saldos em conta-corrente geram o Passivo Externo Líquido 1, retratando a parcela do estoque externo de uma economia que se explica unicamente em função do histórico de transações entre residentes e não residentes (Cysne, 2008). 
Entretanto, conforme (4), o PEL1 e o PEL2 só serão iguais caso não ocorram as variações "V": valorizações ou desvalorizações de ativos e passivos; monetizações ou desmonetizações de ouro; e alocações ou cancelamentos de DES (Direito Especial de Saque).

Além disso, em (5) e (6) apenas se demonstra que o PEL2 é o oposto da PII, e os dois conceitos retratam a diferença de valor do estoque de passivos e ativos externos.

Assim, destaca-se que são as movimentações pelo lado financeiro do balanço de pagamentos que causam modificações nas posições patrimoniais e representam transformações de estoque ou riqueza, afetando a contabilidade da PII; essas movimentações alteram o saldo do Passivo Externo Líquido quando representam uma capacidade (superávit) ou necessidade (déficit) de financiamento resultante das transações correntes. Todavia, como ressaltado, nem todas as mudanças patrimoniais decorrem de transações no BP, já que uma parte delas pode ser derivada das mencionadas variações ("V") de valor. Explicar-se-á adiante como elas se configuram por meio das seguintes identidades ${ }^{4}$ que ligam as diferentes contas da PII em dois pontos distintos no tempo:

$$
\begin{aligned}
& A_{0}+V A A+O M V+G D N=A_{N} \\
& A_{N}-A_{0}=V A A+O M V+G D N \\
& A_{i}=P_{i} \times Q_{i}
\end{aligned}
$$

onde $A_{0}$ e $A_{N}$ são os valores do ativo ou do passivo na estatística de PII em um momento inicial $(i=0)$ e em outro final $\left(i={ }_{N}\right), P_{i}$ é o preço do ativo em um momento $i, Q_{i}$ é a quantidade do ativo em um momento $i$, VAA é o valor associado às quantidades de ativo adquirido ou cedido nas transações registrado no BP, OMV é o valor associado a outras mudanças do volume do ativo, GDN é o valor do ganho de detenção nominal do ativo.

Assim, pode-se considerar a variação de uma conta da PII num intervalo

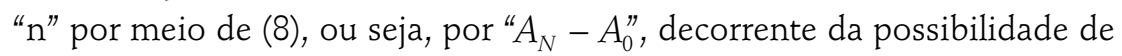
alterações em três variáveis, que são: 
a) VAA: "[...] representam fluxos financeiros explicitados nas transações da conta financeira do BP [...]" (Araujo, 2008, p. 272). Portanto, são aquelas variações na PII causadas pelo volume de ativos e passivos adquiridos e cedidos e que podem ser captadas pela análise do BP, como, por exemplo, um aumento do passivo externo decorrente da contração de um empréstimo, por parte de um residente, em um banco estrangeiro.

b) OMV: têm origem em variações no volume de ativos e passivos não captadas pelo BP, dentre as quais podemos citar: alocação e cancelamento dos direitos especiais de saque do FMI; cancelamento de débitos; monetização e desmonetização de ouro; lançamentos de contrapartida; reclassificações; e medidas de erro (op. cit., p.272-73).

c) GDN: são os ganhos com a detenção de ativos financeiros e não financeiros decorrentes de variações nos preços, dentre elas, a variação da taxa de câmbio. Assim, "[...] os GDN de ativos e passivos financeiros cujos valores são fixados em termos monetários são sempre nulos [...]" (op. cit., p.271), como as dívidas contraídas em dólar, já que essa é a moeda de referência na qual se calcula a PII brasileira. Um exemplo de GDN que não é nulo ocorre nos investimentos em Bolsas de Valores, já que os estoques sofrem variações de valor conforme as modificações das cotações das ações.

Assim, verifica-se por (9) que os valores do ativo ou do passivo na estatística da PII sofrem alterações decorrentes de mudanças nas quantidades e/ou nos preços. Como se pode perceber, as OMV e as VAA são causadas por modificações nas quantidades. Já as GDN são acarretadas por reavaliações nos preços. De tal modo, ao se analisar a identidade (4) - em que "PEL2 = PEL1 + V" -, ressalta-se que a composição da PEL1 é afetada pelas VAA, enquanto OMV e GDN geram "V", que são as valorizações ou desvalorizações de ativos e passivos, monetizações ou desmonetizações de ouro, e alocações ou cancelamentos de DES. Destes três itens de "V":

[...] o mais importante tende a ser o de valorização/desvalorizações, que inclui as reavaliações devidas às modificações de paridade entre a moeda na qual se expressa o balanço e a moeda subjacente na qual se denominam as respectivas aplicações financeiras, reservas internacionais incluidas [...] (Cysne, 2008, p. 2).

Assim, verifica-se que o GDN é a variação ("V") mais relevante; e, considerando que as OMV apresentam variação pouco expressiva, ${ }^{5}$ atribui-se 
valor zero para essa variável no restante do artigo, focando a discussão nos impactos do GDN e das VAA.

\subsection{A vulnerabilidade externa decorrente da Posição Internacional de Investimentos e do fluxo de rendas}

Segundo Reinaldo Gonçalves, [...] vulnerabilidade externa é a probabilidade de resistência a pressões, fatores desestabilizadores e choques externos (Gonçalves, 1999, p. 59).

Como visto na Introdução, a despeito de o tema da vulnerabilidade externa ser amplamente tratado, as análises são geralmente focadas no comércio e, não raramente, sequer consideram as rendas líquidas enviadas ao exterior (Gonçalves, 1998; 2005). É necessário perceber, porém, que existem diversas esferas em que a vulnerabilidade externa se manifesta e o presente artigo pretende contribuir com uma análise da esfera monetário-financeira, procurando inferir de que forma a interação entre os estoques externos e as rendas enviadas/recebidas do exterior influenciam a vulnerabilidade externa.

Essa vulnerabilidade se manifesta de forma patente quando eventos ocorridos fora do país afetam a capacidade de se exercer políticas econômicas domésticas de forma autônoma. Tal processo está geralmente associado com a capacidade de geração de divisas em relação às necessidades, ou seja, pelas condições de oferta e demanda de divisas, principalmente em situações de crise, sendo os países menos vulneráveis externamente os menos afetados pelas mudanças nas condições de liquidez internacional. No tocante à necessidade de divisas, o artigo foca a demanda por moeda estrangeira proveniente de dois fatores: dos estoques externos e dos fluxos de rendas gerados por esses. Assim, a questão da restrição externa pela falta de divisas se desloca do balanço comercial - que recebe mais ênfase nas análises tradicionais, como de Thirlwall (1979) ${ }^{6}$ e seus seguidores - para a balança de rendas e a PII.

Ainda pensando na questão da demanda por divisas, considerar-se-á, neste artigo, uma vulnerabilidade-fluxo e uma vulnerabilidade-estoque, apesar

60 autor considera que as restrições quanto à disponibilidade de divisas tendem a ser o principal obstáculo a níveis mais elevados de demanda agregada, apresentando-se como fator de limitação mais significativo ao crescimento no longo prazo. A disponibilidade de divisas é analisada pelas exportações e importações de bens e serviços não fatores. 
de os dois aspectos estarem relacionados. A vulnerabilidade-fluxo provém da necessidade de divisas decorrente das remessas de rendas. Já a vulnerabilidade-estoque é oriunda das necessidades de moeda estrangeira causadas pelo imperativo de refinanciar os passivos externos e/ou da obrigação de amortizar esses estoques ou liquidá-los quando os seus detentores decidem retirá-los do país. Dessa maneira, os dois aspectos - fluxos e estoques - afetam a necessidade de geração de divisas, criando as condições em que a vulnerabilidade externa se manifesta.

Em relação à vulnerabilidade-estoque, convém observar que: "[...] A acumulação de ativos ou passivos promove igualmente a criação e distribuição de uma outra substância, mais dificilmente mensurável (e cujo nome é quase um tabu entre economistas), e que vem a ser o poder político [...]" (Macedo e Silva; Dos Santos, 2008, p. 15).

Portanto, pode-se considerar que a mera acumulação de um Passivo Externo Líquido elevado significa o aumento da vulnerabilidade externa, ou seja, a diminuição do poder efetivo e uma perda de autonomia na política econômica. ${ }^{7}$ Isso é ainda potencializado pela permanente possibilidade de que os detentores dos estoques resolvam retirá-los do país, criando situações em que os governos tenham como um de seus principais objetivos "agradar" os detentores de riqueza.

Para além da permanente possibilidade de saída dos investimentos que constituem os passivos externos, deve-se levar em conta também que os estoques externos mudam de valor sem ter uma contrapartida nos fluxos do balanço de pagamentos. Nesse sentido, apontou-se na seção anterior que o efeito GDN é o efeito mais importante para explicar essas variações "V" de valor dos estoques. Em relação ao efeito GDN:

The values of real resources and financial items are constantly subject to changes
stemming from either or both of two causes. (a) The price at which transactions in
a certain type of item customarily take place may undergo alteration in terms of
the currency in which that price is quoted. (b) The exchange rate for the currency
in which the price is quoted may change in relation to the unit of account that is
being used. Valuation changes are not included in the balance of payments but
are included in the international investment position (FMI, 2003, p. 9).

Em relação ao item (a) da citação do FMI (2003), não parecem necessárias maiores explicações, ele apenas aponta para o fato de que o efeito GDN

7 "[...] o conceito de vulnerabilidade externa nos remete ao conceito de poder no sistema internacional. O poder efetivo é inversamente proporcional à vulnerabilidade externa [...]" (Gonçalves, 2005, p. 20). 
é influenciado pelos preços de mercado, afinal, "[...] market price is used as the primary basis of valuation" (FMI, 1993, p. 121), ou seja, as oscilações nos preços de mercado dos ativos e passivos externos - que podem ocorrer independentemente das transações no BP - causam modificações na PII.

Já em relação ao item (b) da citação do FMI (2003), é necessária uma discussão mais aprofundada. Isso porque os passivos e os ativos externos podem ser denominados em distintas moedas. ${ }^{8}$ Dessa maneira, não obstante a categorização dos estoques de ativos e passivos na PII corresponder aos componentes da conta financeira do balanço de pagamentos, propõe-se aqui uma separação na estrutura da PII para realizar tal discussão (Quadro 2).

Quadro 2 Posição Internacional de Investimentos (PII)

PII = Ativo Externo Bruto (A) - Passivo Externo Bruto (B)

\begin{tabular}{l|l}
\hline (A) Ativo Externo Bruto (1+2) & (B) Passivo Externo Bruto (3+4) \\
\hline Reservas Internacionais & 3 Passivo em moeda estrangeira \\
2 Estoque de Investimento & 3.1 Dívida Externa Bruta \\
2.1 Investimento direto no exterior & 3.1 .1 Títulos renda fixa emitidos no exterior \\
2.2 Investimento em carteira & 3.1 .2 Outros investimentos \\
2.3 Derivativos & 3.2 Passivo em moeda estrangeira, exclusive \\
2.4 Outros Investimentos & dívida externa \\
& 3.2 .1 Ações emitidas no exterior \\
& 3.2 .2 IDE: Empréstimos intercompanhia \\
& 4 Passivo em moeda doméstica \\
& 4.1 Títulos de renda fixa emitidos no país \\
& 4.2 Ações emitidas no país \\
& 4.3 IDE: Participação no capital \\
\hline
\end{tabular}

Fonte: Dívida Externa Bruta: Cysne (2008, p. 3); passivo denominado em moeda doméstica: elaboração própria, baseada em Biancarelli (2012). Demais itens: Banco Central; (elaboração própria).

Nota: A separação entre as rubricas do passivo externo bruto de acordo com a moeda de denominação pode não ser absolutamente exata, mas, com propósitos analíticos e heurísticos, trata-se certamente de uma boa aproximação. A rubrica "derivativos" é absolutamente insignificante, podendo ser excluída da análise do Passivo Externo Bruto sem nenhum prejuízo.

Assim, distinguem-se as Reservas Internacionais e a Dívida Externa Bruta das categorias restantes. $O$ objetivo é segmentar os passivos externos que são denominados em moeda estrangeira e que representam dívida daqueles que são denominados em moeda nacional; além disso, conforme

8 Entretanto, utiliza-se uma moeda de referência para padronizar a elaboração da PII, da mesma forma como é feito com a mensuração do balanço de pagamentos. No caso brasileiro, a moeda utilizada na contabilização da PII e do BP é o dólar americano. 
se apresentará adiante, os ativos externos também foram separados por uma questão metodológica. Dessa forma, em razão do descasamento de moedas entre os estoques, fica evidente que alterações na taxa de câmbio provocam alterações na PII.

Assim, considerar-se-á as seguintes identidades para realizar a discussão:

$$
\begin{aligned}
& P E b=P_{\text {mest }}+P_{\text {mdom }} \\
& A E b=R E S+E_{\text {dom }} \\
& P E L=\left(P_{\text {mest }}+P_{\text {mdom }}\right)-\left(R E S+E_{\text {dom }}\right) \\
& D E L=D_{\text {ext }}-R E S \\
& P E L=D E L+\left(P_{\text {mest }}-D_{\text {ext }}\right)+\left(P_{\text {mdom }}-E_{\text {dom }}\right) \\
& P E L=\left(P_{\text {mest }}-R E S\right)+\left(P_{\text {mdom }}-E_{\text {dom }}\right)
\end{aligned}
$$

onde $\mathrm{PEb}$ é o passivo externo bruto, $\mathrm{P}_{\text {mest }}$ é o passivo externo em moeda estrangeira, $\mathrm{P}_{\text {mdom }}$ é o passivo externo em moeda doméstica, AEb é o ativo externo bruto, RES são as reservas internacionais, $E_{\text {dom }}$ é o estoque de investimento doméstico no exterior, PEL é o passivo externo líquido, $\mathrm{D}_{\text {ext }}$ é a dívida externa bruta, DEL é a dívida externa líquida.

Em (10) apresenta-se o Passivo Externo bruto, sendo uma parte denominada em moeda estrangeira e outra em moeda doméstica. Como já mencionado, tal segmentação é relevante, pois: "[...] como se sabe da experiência internacional, passivos denominados em moeda doméstica são bem mais confortáveis em momentos de crises externas, tendo em vista que seu valor de mercado em moeda estrangeira costuma reduzir-se automaticamente em tais situações [...]" (Cysne, 2008, p. 4).

A citação de Cysne recupera, portanto, um elemento importante, referente à evolução do valor dos diferentes passivos externos (denominados em moedas doméstica e estrangeira). A ideia implícita é que existe tendência de desvalorização da moeda doméstica (brasileira) em momentos de crise - corroborando com a hipótese de hierarquia das moedas e considerando-se que a moeda brasileira ocupa uma posição periférica nesse sistema -, ou seja, pode-se supor que os passivos externos denominados em 
moeda estrangeira tornam-se maiores nessas situações de crise. Seguindo na análise, os passivos externos denominados em moeda doméstica, num contexto de crise, diminuem de valor em termos da moeda estrangeira não só por conta da desvalorização cambial, mas também graças à queda de seus preços de mercado. Portanto, esses passivos externos brasileiros (denominados em moeda doméstica) tendem a sofrer duplo efeito de desvalorização em momentos de conjuntura desfavorável. ${ }^{9}$ Assim, torna-se bastante desvantajoso para os seus detentores retirar do país esses estoques externos denominados em moeda doméstica nas situações de crise, arrefecendo a demanda por divisas e amenizando a vulnerabilidade-estoque, tanto mais quanto maior for a composição dos passivos externos denominados em moeda doméstica.

Já em (11), apresenta-se o Ativo Externo bruto, que também segue uma divisão metodológica, de forma que as Reservas Internacionais, denominadas em moeda estrangeira e que podem ser utilizadas imediatamente em momentos de crise externa, foram separadas dos Estoques de Investimentos Brasileiros no Exterior, denominados nas moedas dos países em que se localizam, mas que não necessariamente podem ser utilizados de forma imediata em momentos de crise externa.

Em (12), destaca-se que o Passivo Externo Líquido é a diferença entre o Passivo Externo bruto e o Ativo Externo bruto, ou seja, o oposto da PII (que é a diferença entre o Ativo Externo bruto e o Passivo Externo bruto).

Em (13), apresenta-se o importante indicador que é a Dívida Externa Líquida (DEL), obtida pela Dívida Externa Bruta subtraída das Reservas Internacionais, ou seja, por um passivo externo que é denominado em moeda estrangeira e causa dificuldades e m momentos de crise externa, e pela parte do ativo externo que, num momento de tensão e dificuldades cambiais, pode ser imediatamente utilizado para amenizar o problema.

Com esse indicador, é possível boa aproximação das prováveis dificuldades - de liquidez - que essa economia pode incorrer numa crise externa, já que, quanto maior a Dívida Externa Líquida, maiores serão os problemas causados por choques externos.

Já em (14), demonstra-se que o Passivo Externo Líquido pode ser obtido pela soma entre a Dívida Externa Líquida, o Passivo em moeda estrangeira exclusive dívida externa, e a diferença entre o Passivo externo denominado 
em moeda doméstica e o Estoque de Investimento Doméstico no Exterior. Em (14a), a equação verificada em (14) é reescrita, com a anulação da $D_{\text {ext }}$ contida em DEL e a $\mathrm{D}_{\text {ext }}$ que aparece com sinal negativo. A equação fica igual à verificada em (12), apenas com a ordem dos fatores alterada. Fica claro, destarte, que a Dívida Externa Líquida não é o único indicador que deve ser utilizado na análise da vulnerabilidade externa, já que pode levar a conclusões equivocadas a respeito da situação externa das economias, assim como a utilização apenas do passivo externo líquido. Dessa forma, na apreciação da vulnerabilidade-estoque, mostram-se necessários tanto os dados quantitativos (obtidos pela magnitude dos estoques) quanto os qualitativos (representados pela composição dos estoques externos).

Para sair da análise sobre a vulnerabilidade-estoque e iniciar a discussão sobre a vulnerabilidade-fluxo, levar-se-á em conta os diferentes fatores - geralmente ligados aos fluxos econômicos - apresentados pela ortodoxia e pela heterodoxia para explicar a formação dos passivos externos. A corrente ortodoxa geralmente atribui o aumento do passivo externo líquido (PEL1) a um excesso de gasto doméstico sobre a renda doméstica, conforme o trecho abaixo:

Em particular, o PEL1 se eleva se, e somente se, a absorção líquida de bens e serviços de certa economia se mostra, durante o período contábil em questão, superior ao Produto Nacional Bruto (PNB) medido a preços de mercado. Ou, equivalentemente, se o país absorve poupança externa, investindo mais do que poupa internamente (Cysne, 2008, p. 4).

Na mesma linha, Ribeiro (2013, p. 3) propõe que:

O saldo em transações correntes de um país é reflexo direto das condições de poupança e de investimento doméstico. Países deficitários em suas transações correntes são países que enfrentam, de maneira sistemática, uma escassez de poupança doméstica frente ao nivel de investimento realizado, o que, em termos macroeconômicos, equivale a uma demanda doméstica persistentemente superior à oferta doméstica de bens e serviços.

Os argumentos de cunho heterodoxo, por sua vez, preferem apontar outros aspectos em vez de enfatizar a associação de que um déficit em transações correntes significa um excesso de investimento sobre a poupança, como fica evidente pelo trecho a seguir,

[...] em determinado instante do tempo, o país pode ser superavitário em termos de balança comercial e serviço de não fatores, isto é, consumir menos do que produz e, apesar disso, o saldo em transações correntes, como definido, ser deficitário, devido ao pagamento de juros [ou melhor, pagamento de rendas]. Ou seja, o país realiza uma transferência líquida de recursos ao exterior, mas esta pode ser insuficiente para compensar a renda líquida enviada ao exterior [...] (Gremaud et al., 2009, p. 276; a parte grifada é acréscimo nosso). 
Apesar de estarem corretas, as duas visões apresentadas por Cysne (2008) e Gremaud et al. (2009) evidentemente destacam aspectos diferentes. Assim, o sentido que conferem ao déficit das transações correntes acaba sendo muito distinto. No primeiro caso, para Cysne, é enfatizado excesso de gastos sobre a renda. Já no segundo, para Gremaud, percebe-se que as rendas líquidas enviadas ao exterior são muito importantes na análise desse déficit externo.

Desta maneira, parece fundamental analisar a identidade obtida em Araujo (2008):

$$
R D=Y-R L E E=P N B
$$

onde RD é a renda doméstica, Y é o produto, RLEE é a renda líquida enviada ao exterior, PNB é o produto nacional bruto.

Como fica evidente em Cysne (2008), o déficit nas transações correntes só ocorrerá caso a absorção de bens e serviços seja superior ao Produto Nacional Bruto (PNB). Contudo, o ponto que se tenta destacar, por meio da equação (15), é que o PNB é afetado pela renda líquida enviada ao exterior (RLEE). Ou seja, nas diversas análises (e.g. Garcia, 2001) que se referem a uma "insuficiência de poupança doméstica" como a causa do desequilíbrio das transações externas, não se encontra a devida ênfase na despoupança causada pelas rendas líquidas enviadas ao exterior.

Essa discussão poderia ser tratada como um simples manuseio de identidades, contudo, não o é, já que as implicações decorrentes são muito importantes. Afinal, quando os déficits nas transações correntes unicamente são tratados como um excesso de investimento sobre a poupança, tem-se a impressão de uma economia que está sendo ajudada pelos ingressos estrangeiros, ou, dito de outra maneira, pode-se considerar essa economia como "perdulária", legitimando as "receitas" de melhoria das contas externas preconizadas pelo FMI. ${ }^{10}$

Entretanto, a PII negativa (passivo externo líquido desfavorável) tende a gerar "fuga/transferência de excedente" da economia doméstica para a estrangeira, por meio dos pagamentos dos fluxos de rendas produzidos por

10 "O FMI financia o ajuste das contas externas dos países em desenvolvimento com base em acordos que envolvem condicionalidades. $O$ enfoque do FMI para o ajuste das contas externas está na redução dos gastos da economia. Essa redução é provocada, fundamentalmente, por políticas macroeconômicas restritivas. Não é por outra razão que o ajuste fiscal é o critério de desempenho mais importante usado pelo FMI para liberar seus recursos" (Gonçalves, 2005, p. 177). 
esses estoques externos, permitindo a hipótese de que a PII desfavorável esteja, em algum grau, na causa da mencionada "insuficiência de poupança doméstica", e não que seja a sua consequência.

Portanto, atentando-se ao fato de que a interação entre a PII e as rendas líquidas enviadas ao exterior exerce grande influência sobre a vulnerabilidade externa, o enfoque da discussão passa a ser outro, já que esses rendimentos decorrentes dos estoques de ativos e passivos externos podem ser analisados como estando na origem da permanente necessidade de geração de divisas e da persistente perda de recursos por parte dos países deficitários em rendas, acentuando ou até mesmo causando a situação de "insuficiência de poupança". A ideia implícita nesse raciocínio é a de que as entradas de divisas ocasionadas pelos financiamentos externos e as saídas por conta das amortizações e das rendas significam, intertemporalmente, perda líquida de divisas. ${ }^{11}$ Assim, a vulnerabilidade-fluxo é em grande medida decorrente dessa necessidade de divisas para pagar as rendas dos estoques externos. Diante do exposto, pode-se observar que:

$O$ aumento da vulnerabilidade se manifesta na maior fragilidade do país, tanto em conduzir sua política econômica, como em contágio de crises externas. No âmbito das finanças, a vulnerabilidade está associada à crescente dependência de recursos externos para cobrir as necessidades de financiamento do BP (Lacerda, 2004, p. 71).

Essa necessidade de financiamento do BP brasileiro é em grande parte decorrente das remessas de rendas relativas aos estoques externos. No Brasil, em termos históricos, pode-se observar que a economia é estruturalmente deficitária em rendas. ${ }^{12}$ Esses recursos enviados ao exterior determinam permanente necessidade de geração de divisas, geralmente não satisfeita pelo "lado real"13 da economia (superávits da balança comercial e de serviços), fazendo com que o país fique dependente do financiamento externo para fechar suas contas externas, constituindo-se essa condição, portanto, em uma das causas da vulnerabilidade externa brasileira, sobretudo em momentos de reversão do ciclo internacional de liquidez.

Dessa forma, um dos elos mais importantes dessa interação entre fluxos e estoques está na sua circularidade, ou seja, a Posição Internacional de Inves-

11 Isso fica evidente ao verificar-se que o valor de um empréstimo é menor do que a soma da amortização e dos juros.

12 De acordo com dados do Banco Central, em todos os anos da série houve déficits nessa conta das transações correntes.

13 Considerando as rendas como pertencentes ao "lado financeiro". 
timentos negativa causa uma saída de rendas, e esse fluxo está diretamente relacionado com o aumento do passivo externo (e queda da própria PII).

Pode-se considerar que um importante fator definidor da vulnerabilidade-fluxo, sob a ótica do presente estudo, são os desequilíbrios entre os estoques de passivo e ativo externo, que geram fluxos de rendas registrados no balanço de pagamentos (BP), acabando por condicionar o lado real e financeiro das outras contas do BP, especialmente no caso dos deficitários em rendas, muitas vezes obrigados a atrelar suas estratégias de inserção externa à necessidade de geração de divisas para fazer frente aos desequilíbrios entre seus passivos e ativos externos.

Assim, chega-se a uma constatação essencial: na análise da vulnerabilidade-fluxo, deve-se considerar não apenas a magnitude dos valores acumulados dos estoques externos, mas também as rentabilidades observadas desses. Isso porque muitas análises, dentre elas Simonsen e Cysne (2007), consideram uma taxa de remuneração sobre o saldo do passivo externo líquido, ${ }^{14}$ ou seja, acabam desconsiderando o diferencial de rentabilidade entre os estoques externos dos diversos países.

Tal método é insuficiente para analisar a questão da vulnerabilidade externa no presente estudo, afinal, não leva em conta a hierarquia no sistema monetário internacional, em que os países com moeda central - ou no núcleo do sistema monetário internacional - apresentam maiores facilidades em manejar suas políticas econômicas e conseguem manter uma taxa de juros menor do que os periféricos sem gerar fuga de capital.

Assim, um país emissor de moeda central pode ter um ativo externo menor que o passivo externo e mesmo assim obter uma entrada líquida de rendas em razão de uma rentabilidade mais elevada daquele em relação a este. ${ }^{15}$ Neste artigo, isso será chamado de efeito rentabilidade favorável, que evidencia a pequena adequabilidade da hipótese de Simonsen e Cysne (2007).

14 A derivada em relação ao tempo do passivo externo líquido seria igual a " $d=\mathrm{iD}-\mathrm{H}$ ", sendo: $d$ = derivada em relação ao tempo do passivo externo líquido; $\mathrm{i}=$ taxa média de remuneração dos capitais externos; $\mathrm{D}$ = Passivo externo líquido; $\mathrm{H}$ : transferência líquida de recursos para o exterior (Simonsen; Cysne, 2007).

$15 \mathrm{Tal}$ fato ocorreu, por exemplo, nos Estados Unidos, no ano de 2000. Os haveres dos Estados Unidos no resto do mundo (ativo externo) somavam US\$ 3.488 bilhões, enquanto os haveres do resto do mundo nos Estados Unidos (passivo externo) eram de 6.446 bilhões de dólares. Entretanto, ocorreu uma entrada de rendas de US\$353 bilhões, ao passo que as saídas de rendas desse país foram de apenas US\$ 331 bilhões (Duménil; Lévy, 2005, p. 96-97). Ou seja, não obstante os Estados Unidos ostentarem um passivo externo maior que o ativo externo, ocorreu entrada líquida de rendas no ano de 2000 graças ao diferencial de rentabilidade entre os ativos e os passivos externos. 
De tal forma, considerar-se-á que a vulnerabilidade-fluxo é crescente quando a rentabilidade do passivo externo aumenta e decrescente com a elevação da rentabilidade do ativo externo. Assim, o diferencial entre essas taxas é fundamental para as análises.

Em suma, considerou-se a vulnerabilidade externa decorrente da PII e do fluxo de rendas com foco nos seguintes aspectos: i) passivos externos maiores do que os ativos externos; ii) composição da PII desfavorável - quando o passivo externo é preponderantemente denominado em moedas estrangeiras sem uma correspondência em reservas internacionais -, gerando grande necessidade de divisas pela saída dos investimentos que compõem o passivo externo; e efeito rentabilidade desfavorável nos estoques externos. Esses aspectos perpetuam a vulnerabilidade externa quando redundam em um efeito circular entre a PII e as rendas que ele gera (retroalimentação entre fluxos e estoques), resultando num crescimento endógeno do passivo externo líquido. Essa vulnerabilidade externa acaba se manifestando de forma mais acentuada em momentos de reversão dos ciclos de liquidez, que escasseiam o financiamento que alimentava a mencionada circularidade, forçando a economia a gerar divisas na esfera real para pagar as rendas dos estoques externos. A situação se agrava ainda mais quando o país tem de amortizar uma parte desses estoques. Nesse contexto, a economia fragilizada que tenta produzir saldos positivos através da transferência de recursos reais ao exterior corre dois riscos principais: em primeiro lugar, pode sofrer de ajustes recessivos caso adote uma estratégia agressiva de diminuir a absorção interna para gerar aumento das exportações líquidas; em segundo lugar, pode conviver com pressões inflacionárias por conta de desvalorizações cambiais que visem aumentar a competitividade externa dos produtos domésticos.

\section{Posição Internacional de Investimentos e vulnerabi- lidade externa no Brasil: a primeira década dos anos 2000}

\subsection{Evolução da Posição Internacional de Investimentos brasileira no período $2001-2010$}

Apresenta-se, na Tabela 1, a Posição Internacional de Investimentos (PII) da economia brasileira na primeira década dos anos 2000 (2001-2010). 
A PII foi negativa durante todo o período, ou seja, o passivo externo bruto foi maior do que o ativo externo bruto nesses anos.

Tabela 1 Posição Internacional de Investimentos do Brasil, (US\$ bilhões), 2001-2010

\begin{tabular}{lrr|r|r|r|r|r|r|r|r}
\hline Discriminação & $\mathbf{2 0 0 1}$ & $\mathbf{2 0 0 2}$ & $\mathbf{2 0 0 3}$ & $\mathbf{2 0 0 4}$ & $\mathbf{2 0 0 5}$ & $\mathbf{2 0 0 6}$ & $\mathbf{2 0 0 7}$ & $\mathbf{2 0 0 8}$ & $\mathbf{2 0 0 9}$ & $\mathbf{2 0 1 0}$ \\
\hline PII (A-B) & $-265,0$ & $-230,5$ & $-272,5$ & $-297,6$ & $-316,6$ & $-368,9$ & $-540,5$ & $-283,4$ & $-600,8$ & $-677,4$ \\
\hline Ativo (A) & 107,1 & 112,9 & 134,2 & 148,5 & 168,2 & 238,9 & 379,8 & 408,2 & 479,1 & 616,3 \\
\hline $\begin{array}{l}\text { Investimento direto } \\
\text { brasileiro no exterior }\end{array}$ & 49,7 & 54,4 & 54,9 & 69,2 & 79,3 & 113,9 & 139,9 & 155,7 & 164,5 & 189,2 \\
\hline $\begin{array}{l}\text { Investimentos em } \\
\text { carteira }\end{array}$ & 6,4 & 5,8 & 7,0 & 9,4 & 10,8 & 14,4 & 19,5 & 14,9 & 16,5 & 37,6 \\
\hline Derivativos & 0,0 & 0,1 & 0,1 & 0,1 & 0,1 & 0,1 & 0,1 & 0,6 & 0,4 & 0,8 \\
\hline Outros investimentos & 15,1 & 14,7 & 23,0 & 16,9 & 24,2 & 24,6 & 39,9 & 43,2 & 59,1 & 100,0 \\
\hline Ativos de reservas & 35,9 & 37,8 & 49,3 & 52,9 & 53,8 & 85,8 & 180,3 & 193,8 & 238,5 & 288,6 \\
\hline Passivo (B) & 372,1 & 343,4 & 406,7 & 446,1 & 484,8 & 607,7 & 920,3 & 691,6 & 1079,9 & 1293,6 \\
\hline $\begin{array}{l}\text { Investimento } \\
\text { estrangeiro direto }\end{array}$ & 121,9 & 100,9 & 132,8 & 161,3 & 181,3 & 220,6 & 309,7 & 287,7 & 400,8 & 472,6 \\
\hline $\begin{array}{l}\text { Investimentos em } \\
\text { carteira }\end{array}$ & 151,7 & 137,4 & 166,1 & 184,8 & 232,4 & 303,6 & 509,6 & 287,5 & 561,8 & 656,3 \\
\hline Derivativos & 0,0 & 0,2 & 0,1 & 0,3 & 0,2 & 0,4 & 1,8 & 2,5 & 3,4 & 3,8 \\
\hline Outros investimentos & 98,3 & 105,0 & 107,7 & 99,8 & 70,9 & 83,1 & 99,2 & 113,9 & 113,8 & 161,0 \\
\hline
\end{tabular}

Fonte: Banco Central do Brasil.

Nota: Os dados se referem ao dia 31 de dezembro de cada ano.

O fluxo de capitais no período refletiu-se na evolução da PII pelo aumento do passivo externo bruto e pela mudança de sua composição, expressa no aumento da participação do investimento direto e de carteira, e pela diminuição da dívida externa, como ficará claro abaixo. Pelo lado dos ativos, destaca-se o expressivo crescimento das reservas internacionais.

Biancarelli (2011) já mostra que os investimentos em carteira representavam em 2010 a maior conta do passivo externo, o que significaria uma deterioração da situação patrimonial do país, já que considera esses investimentos mais voláteis e passíveis de sair do país com mais facilidade. Contudo, à semelhança da discussão realizada na seção anterior, o autor aponta que esse tipo de estoque externo tende a se desvalorizar duplamente em momentos de crise (efeito câmbio e queda de preços), diminuindo os eventuais problemas que possam causar nesses momentos.

A despeito da preponderância dos investimentos em carteira em quase todos os anos da década, nota-se, pela Tabela 1, que o Brasil tem sido 
também um importante receptor de investimentos diretos estrangeiros; ${ }^{16}$ recentemente, porém, as corporações brasileiras têm aumentado seus investimentos no exterior, configurando um novo padrão de inserção no sistema produtivo e comercial mundial, com expressivo crescimento desse tipo de ativo externo.

Um fator fundamental de se apresentar é a mudança na composição do passivo externo brasileiro de acordo com a moeda de denominação. O Gráfico 1 mostra que o passivo denominado em moeda doméstica aumentou sua participação de aproximadamente $30 \%$ para $60 \%$ ao longo da década. Nesse aspecto, pode-se considerar, conforme apresentado na seção anterior, que a economia brasileira reduziu sua vulnerabilidade-estoque, afinal, essa menor participação do passivo externo em moeda estrangeira reduz sensivelmente os potenciais problemas em momentos de crise.

\section{Gráfico 1 Composição do passivo externo brasileiro: parcela do passivo denominado em moeda doméstica, (\%), 2001-2010}

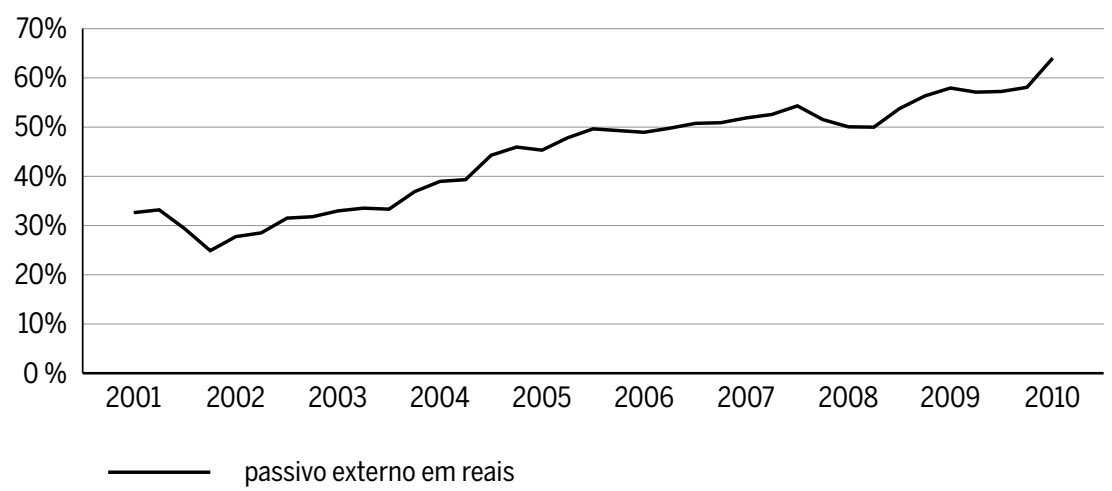

Fonte: Elaboração própria baseada em Biancarelli (2012) e com dados do Banco Central do Brasil.

Notas: (1) O passivo denominado em moeda doméstica foi considerado como a soma entre os títulos de renda fixa emitidos no país, as ações emitidas no país e o investimento direto estrangeiro relativo à "participação no capital"; (2) Os dados são trimestrais e se referem ao último dia dos meses de março, junho, setembro e dezembro de cada ano.

16 Segundo Prates et al. (2011), a partir de 2004 há um movimento de retomada dos investimentos diretos estrangeiros em muitos países periféricos, determinado notadamente pelo dinamismo econômico desses países e - de forma associada - pela alta no preço das commodities. 
Entretanto, deve-se fazer uma ressalva ao raciocínio anterior. Não obstante os efeitos benignos desse tipo de composição do passivo externo sobre a vulnerabilidade externa, é fundamental confrontar esses dados com o tamanho das reservas internacionais, ativos externos de liquidez imediata.

Nesse sentido, o Gráfico 2 mostra mais uma mudança positiva para a vulnerabilidade externa da economia brasileira, afinal, as reservas internacionais se tornam maiores do que a dívida externa, fazendo com que a dívida externa líquida (DEL) se torne negativa, significando, conforme apresentado, menores dificuldades em momentos de crise. ${ }^{17}$

\section{Gráfico 2 Dívida externa e reservas brasileiras (US\$ bilhões), 2001-2010}

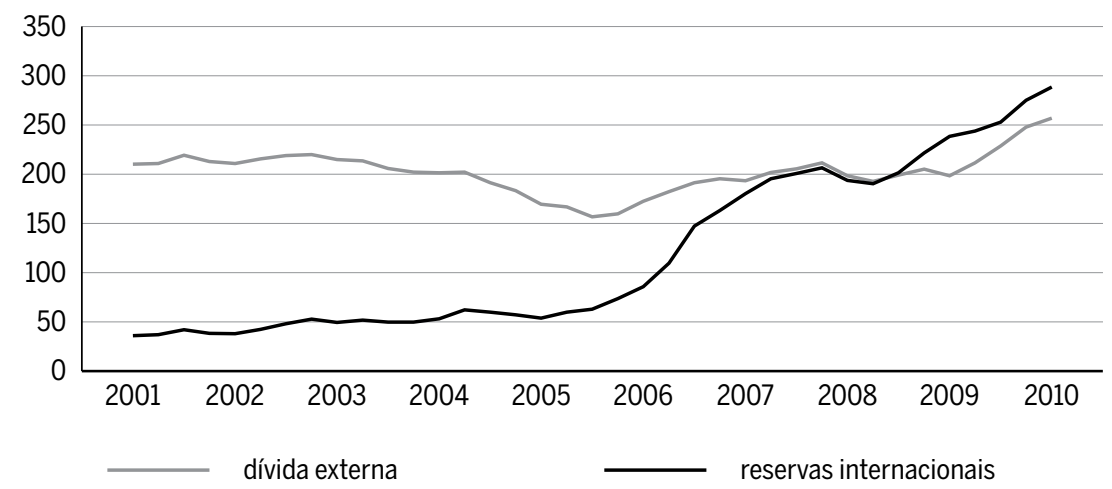

Fonte: Banco Central; elaboração própria.

Nota: A dívida externa foi considerada como a soma entre os títulos de renda fixa emitidos no exterior e os outros investimentos.

Em suma, pode-se considerar que a vulnerabilidade-estoque da economia brasileira, sob a ótica do presente estudo, diminuiu; afinal, o país conta com a segurança, nos momentos de crise, de que suas reservas internacionais cubram a dívida externa. Completando o raciocínio, vale reforçar que o passivo externo denominado em moeda doméstica tende a sofrer duplo efeito de desvalorização nos momentos de crise e ele se tornou majoritário na composição da PII. Logo, diminui o ímpeto de saída de divisas para fazer frente aos estoques justamente nas situações de maiores dificuldades, visto que ela implica grandes perdas para os investidores que quiserem 17 Para uma análise mais detalhada sobre a dívida externa brasileira no período recente, ver Prates e Cunha (2013). 
retirar seu capital do país nesse momento. Para verificar tal hipótese, pode-se analisar o ano de 2008, ápice da crise financeira mundial e justamente o momento em que o passivo externo sofre grande perda de valor (Tabela 1). ${ }^{18}$ Parece razoável supor, portanto, que o Brasil não foi tão afetado pela crise nesse âmbito justamente por conta da diminuição dessa vulnerabilidade externa decorrente da PII.

\subsection{Rendas líquidas enviadas ao exterior}

Conforme apresentado, o Brasil é estruturalmente deficitário em rendas. ${ }^{19}$ A Tabela 2 confirma essa condição para o período 2001-2010, inclusive com aumento desse déficit.

Tabela 2 Brasil: Rendas recebidas e enviadas ao exterior (US\$ milhões), 2001-2010

\begin{tabular}{l|r|r|r|r|r|r|r|r|r|r}
\hline Discriminação & $\mathbf{2 0 0 1}$ & $\mathbf{2 0 0 2}$ & $\mathbf{2 0 0 3}$ & $\mathbf{2 0 0 4}$ & $\mathbf{2 0 0 5}$ & $\mathbf{2 0 0 6}$ & $\mathbf{2 0 0 7}$ & $\mathbf{2 0 0 8}$ & $\mathbf{2 0 0 9}$ & $\mathbf{2 0 1 0}$ \\
\hline Salário e ordenado & 95 & 102 & 109 & 181 & 214 & 177 & 448 & 545 & 603 & 498 \\
\hline $\begin{array}{l}\text { Renda de investimen- } \\
\text { to direto }\end{array}$ & -4.638 & -4.983 & -5.098 & -5.789 & -10.302 & -12.826 & -17.489 & -26.775 & -19.742 & -25.504 \\
\hline $\begin{array}{l}\text { Renda de investimen- } \\
\text { to em carteira }\end{array}$ & -9.621 & -8.384 & -8.743 & -10.415 & -11.778 & -11.028 & -7.065 & -8.039 & -9.213 & -9.964 \\
\hline $\begin{array}{l}\text { Renda de outros } \\
\text { investimentos }\end{array}$ & -5.579 & -4.925 & -4.820 & -4.497 & -4.101 & -3.803 & -5.185 & -6.293 & -5.332 & -4.517 \\
\hline Rendas & -19.743 & -18.191 & -18.552 & -20.520 & -25.967 & -27.480 & -29.291 & -40.562 & -33.684 & -39.486 \\
\hline
\end{tabular}

Fonte: Banco Central do Brasil.

A tabela mostra grande aumento do déficit nas rendas líquidas enviadas ao exterior no ano de eclosão da crise mundial, passando de aproximadamente US\$ 29 bilhões em 2007 para US\$ 41 bilhões em 2008 (Tabela 2). Tal fato esteve diretamente ligado ao comportamento da renda relativa aos investimentos estrangeiros diretos; afinal, o déficit com essa rubrica passou de aproximadamente US\$ 17 bilhões para US $\$ 27$ bilhões nos anos em questão. Nota-se, portanto, que o passivo externo na forma de inves-

18 Passando de US\$ 920 bilhões em 2007 para US\$ 692 bilhões em 2008, especialmente pela expressiva queda do estoque dos investimentos em carteira (que diminuíram em mais de US\$ 200 bilhões no ano de 2008). Enquanto isso, o ativo externo brasileiro até aumentou durante esse ano.

19 Tal situação já era esperada de acordo com os dados da PII brasileira mostrados na subseção anterior; afinal, o passivo externo brasileiro é consideravelmente maior do que o ativo externo. 
timento estrangeiro direto deve sim ser considerado nas análises sobre a vulnerabilidade externa, porque, se por um lado a Receita Federal (2012) o aponta como um estoque que não tende a sair do país nos momentos de crise (diminuindo a vulnerabilidade-estoque), por outro gera pressão de saída de divisas por conta das rendas líquidas enviadas ao exterior ${ }^{20}$ (aumentando a vulnerabilidade-fluxo).

\subsection{Relação entre fluxos e estoques com base na Posição Interna- cional de Investimentos}

Após a apresentação dos estoques dos passivos e dos ativos externos da economia brasileira na primeira década dos anos 2000 e da análise dos fluxos de rendas por eles gerados, é possível estimar o que pode ser considerado como uma taxa de apropriação de rendas oriundas da posse de ativos externos, valendo-se da Posição Internacional de Investimentos e de suas diversas contas. Para tanto, a metodologia adotada é semelhante à de Duménil e Lévy (2005), realizada pela divisão entre o fluxo de renda de uma determinada conta, durante um ano, e o valor do estoque dessa conta no final do mesmo ano (Tabela 3). Essa relação não apresenta propriamente a rentabilidade dos ativos, já que não diz respeito exatamente ao que cada ativo rendeu, mas ao montante dessa rentabilidade apropriada pelo detentor do ativo. A despeito disso, é inquestionável que essa razão entre fluxos e estoques guarda relação com a rentabilidade dos ativos, podendo elucidar alguns aspectos interessantes para a análise da vulnerabilidade externa.

De acordo com a Tabela 3, podem-se fazer algumas análises com base na razão entre fluxos e estoques da PII e do BP. Em primeiro lugar, a rentabilidade do ativo externo nesse período parece ter sido significativamente menor do que a do passivo externo. ${ }^{21}$ Isso é coerente com a abordagem da hierarquia das moedas e indica que a economia brasileira apresentou situação desfavorável sob a ótica do Efeito Rentabilidade. ${ }^{22}$

20 Isso pode ocorrer, por exemplo, para salvar as matrizes em dificuldades.

21 Os valores exatos não são relevantes, mas os resultados mostram distintos patamares para a razão entre fluxos e estoques dos ativos e dos passivos externos, e isso sim é significativo para análises de vulnerabilidade externa.

22 Pode-se considerar, conforme apresentado em seção anterior, que a vulnerabilidade externa na esfera financeira é diretamente relacionada com a rentabilidade do passivo externo, ou seja, quanto maior essa rentabilidade em relação àquela dos ativos externos, mais vulnerável 
Tabela 3 Relação entre fluxos e estoques da Posição Internacional de Investimentos e do balanço de pagamentos brasileiros (\%), 2001-2010

\begin{tabular}{|c|c|c|c|c|c|c|c|c|c|c|}
\hline Discriminação & 2001 & 2002 & 2003 & 2004 & 2005 & 2006 & 2007 & 2008 & 2009 & 2010 \\
\hline $\begin{array}{l}\text { Investimento direto } \\
\text { brasileiro no exterior }\end{array}$ & $0,7 \%$ & $1,8 \%$ & $1,6 \%$ & $1,6 \%$ & $0,9 \%$ & $0,9 \%$ & $1,6 \%$ & $1,3 \%$ & $0,8 \%$ & $0,6 \%$ \\
\hline $\begin{array}{l}\text { Participação no } \\
\text { capital }\end{array}$ & $0,6 \%$ & $2,0 \%$ & $1,7 \%$ & $1,7 \%$ & $1,0 \%$ & $1,0 \%$ & $1,0 \%$ & $1,3 \%$ & $0,9 \%$ & $0,5 \%$ \\
\hline $\begin{array}{l}\text { Empréstimos } \\
\text { intercompanhia }\end{array}$ & $1,4 \%$ & $1,0 \%$ & $1,2 \%$ & $1,3 \%$ & $0,7 \%$ & $0,9 \%$ & $3,7 \%$ & $1,1 \%$ & $0,3 \%$ & $1,0 \%$ \\
\hline $\begin{array}{l}\text { Investimentos } \\
\text { em carteira }\end{array}$ & - & - & - & - & & & - & 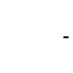 & - & \\
\hline $\begin{array}{l}\text { Investimentos em } \\
\text { ações }\end{array}$ & $0,0 \%$ & $0,0 \%$ & $0,1 \%$ & $0,2 \%$ & $0,4 \%$ & $0,6 \%$ & $0,2 \%$ & $0,3 \%$ & $0,5 \%$ & $0,0 \%$ \\
\hline Títulos de renda fixa & - & - & - & - & - & - & - & - & - & \\
\hline Outros investimentos & $7,8 \%$ & $4,4 \%$ & $3,7 \%$ & $5,9 \%$ & $5,6 \%$ & $7,8 \%$ & $4,6 \%$ & $2,5 \%$ & $1,8 \%$ & $0,8 \%$ \\
\hline Ativos de reservas & $4,1 \%$ & $3,7 \%$ & $2,7 \%$ & $1,4 \%$ & $1,4 \%$ & $3,6 \%$ & $3,8 \%$ & $4,5 \%$ & $2,4 \%$ & $1,7 \%$ \\
\hline Ativo (A) & $3,1 \%$ & $2,9 \%$ & $2,5 \%$ & $2,2 \%$ & $1,9 \%$ & $2,7 \%$ & $3,0 \%$ & $3,1 \%$ & $1,8 \%$ & $1,2 \%$ \\
\hline $\begin{array}{l}\text { Investimento direto } \\
\text { estrangeiro }\end{array}$ & $4,1 \%$ & $5,9 \%$ & $4,5 \%$ & $4,3 \%$ & $6,1 \%$ & $6,3 \%$ & $6,4 \%$ & $10,0 \%$ & $5,2 \%$ & $5,6 \%$ \\
\hline $\begin{array}{l}\text { Participação no } \\
\text { capital }\end{array}$ & $3,5 \%$ & $5,8 \%$ & $4,3 \%$ & $4,1 \%$ & $6,0 \%$ & $6,4 \%$ & $6,8 \%$ & $12,0 \%$ & $5,9 \%$ & $6,5 \%$ \\
\hline $\begin{array}{l}\text { Empréstimos } \\
\text { intercompanhia }\end{array}$ & $7,4 \%$ & $5,6 \%$ & $5,0 \%$ & $4,5 \%$ & $6,3 \%$ & $5,2 \%$ & $1,6 \%$ & $2,2 \%$ & $2,5 \%$ & $2,0 \%$ \\
\hline $\begin{array}{l}\text { Investimentos } \\
\text { em carteira }\end{array}$ & $7,3 \%$ & $7,1 \%$ & $6,1 \%$ & $6,0 \%$ & $5,4 \%$ & $4,6 \%$ & $2,8 \%$ & $5,8 \%$ & $2,7 \%$ & $2,3 \%$ \\
\hline $\begin{array}{l}\text { Investimentos } \\
\text { em ações }\end{array}$ & $4,1 \%$ & $4,1 \%$ & $3,0 \%$ & $3,1 \%$ & $2,8 \%$ & $2,6 \%$ & $1,6 \%$ & $5,7 \%$ & $2,0 \%$ & $1,6 \%$ \\
\hline Títulos de renda fixa & $8,3 \%$ & $7,8 \%$ & $7,5 \%$ & $8,1 \%$ & $8,4 \%$ & $8,2 \%$ & $5,7 \%$ & $5,9 \%$ & $4,1 \%$ & $3,6 \%$ \\
\hline Outros investimentos & $6,9 \%$ & $5,3 \%$ & $5,3 \%$ & $5,5 \%$ & $7,7 \%$ & $6,9 \%$ & $7,1 \%$ & $6,5 \%$ & $5,6 \%$ & $3,3 \%$ \\
\hline Passivos (A) & $6,2 \%$ & $6,3 \%$ & $5,4 \%$ & $5,3 \%$ & $6,0 \%$ & $5,6 \%$ & $4,4 \%$ & $7,7 \%$ & $3,9 \%$ & $3,6 \%$ \\
\hline
\end{tabular}

Fonte: Banco Central; elaboração própria.

Notas: (1) Metodologia: valor do fluxo do balanço de pagamentos ao longo do ano/valor do estoque da Posição Internacional de Investimentos em 31 de dezembro do mesmo ano; (2) a forma como são disponibilizados os dados do BP dificulta diferenciar a parcela das rendas proveniente dos títulos de renda fixa daquela que advém dos ativos de reserva; optou-se por considerar que toda essa renda foi proveniente dos ativos de reservas. 
Em segundo lugar, verificam-se, de acordo com a Tabela 3, alterações na rentabilidade aparente dos passivos externos, especialmente pelo aumento da rentabilidade dos investimentos diretos ao longo do período.

Em terceiro lugar, ainda sobre a rentabilidade dos investimentos estrangeiros diretos, vale frisar o grande salto ocorrido no ano de 2008. Dessa forma, pode-se considerar que, no âmbito da crise, o estoque na forma de investimento estrangeiro direto foi o que gerou, proporcionalmente, maior pressão por geração de divisas (viés contracíclico do envio de lucros).

\subsection{A vulnerabilidade externa decorrente da Posição Internacio- nal de Investimentos e do fluxo de rendas da economia brasileira: análise do período 2001-2010}

Na Tabela 4, é feita uma estimativa dos fatores que levaram à variação anual do saldo da PII, comparando essa variação com o saldo das transações correntes - lembrando que os fluxos financeiros por si sós não alteram o saldo da PII. A diferença de valor entre essas duas variáveis (variação anual do saldo da PII e do saldo anual das transações correntes) foi atribuída, por simplificação, ao fator $\mathrm{GDN},{ }^{23}$ decorrente das variações de preço dos estoques. Portanto, pela metodologia adotada na seção anterior, a variação anual do saldo da PII pode ser causada por dois fatores: a) pelo saldo das transações correntes; b) pelo efeito GDN.

Assim, por exemplo, em 2005, de acordo com os dados da Tabela 4, o saldo das transações correntes foi positivo em 14 bilhões de dólares, e a variação do saldo da PII no mesmo ano foi de -19 bilhões de dólares, ou seja, pela metodologia adotada concluímos que $-74 \%$ da variação do saldo da PII para esse ano foi causada pelo superávit das transações correntes e em 174\% ocasionada pelo efeito GDN. Isso implica que, apesar do saldo positivo em transações correntes, o passivo externo líquido aumentou no ano de 2005. Esse resultado, não trivial, demarca uma nova configuração da evolução dos estoques externos, e o "endividamento" líquido de um país pode aumentar mesmo quando ele apresentar uma capacidade de financiamento decorrente de saldos positivos nas transações correntes. Esse fato, aparentemente contraditório, é explicado pelas variações de preços dos estoques externos.

23 A rigor, essa diferença pode ser decorrente também do efeito OMV, mas, conforme exposto anteriormente, esse efeito é insignificante. 
Tabela 4 Brasil: PII e transações correntes (US\$ bilhões). Determinantes das variações do saldo anual da PII (\%). Indicadores em relação ao PIB (\%) - (2001-2010)

\begin{tabular}{l|r|r|r|r|r|r|r|r|r|r|r}
\hline Discriminação & $\mathbf{2 0 0 1}$ & $\mathbf{2 0 0 2}$ & $\mathbf{2 0 0 3}$ & $\mathbf{2 0 0 4}$ & $\mathbf{2 0 0 5}$ & $\mathbf{2 0 0 6}$ & $\mathbf{2 0 0 7}$ & $\mathbf{2 0 0 8}$ & $\mathbf{2 0 0 9}$ & $\mathbf{2 0 1 0}$ & Período \\
\hline Rendas & $-19,7$ & $-18,2$ & $-18,6$ & $-20,5$ & $-26,0$ & $-27,5$ & $-29,3$ & $-40,6$ & $-33,7$ & $-39,5$ & $-273,5$ \\
\hline Outras & $-3,5$ & 10,6 & 22,7 & 32,2 & 40,0 & 41,1 & 30,8 & 12,4 & 9,4 & $-7,8$ & 187,9 \\
\hline $\begin{array}{l}\text { Transações } \\
\text { Correntes }\end{array}$ & $-23,2$ & $-7,6$ & 4,2 & 11,7 & 14,0 & 13,6 & 1,6 & $-28,2$ & $-24,3$ & $-47,3$ & $-85,6$ \\
\hline PII & $-265,0$ & $-230,5$ & $-272,5$ & $-297,6$ & $-316,6$ & $-368,9$ & $-540,5$ & $-283,4$ & $-600,8$ & $-677,4$ & s.v \\
\hline $\begin{array}{l}\text { Variação anual } \\
\text { da PII }\end{array}$ & s.v. & 34,4 & $-42,0$ & $-25,1$ & $-19,0$ & $-52,3$ & $-171,6$ & 257,1 & $-317,4$ & $-76,6$ & $-412,4$ \\
\hline $\begin{array}{l}\text { Rendas/ } \\
\text { variação PII }\end{array}$ & s.v. & $-53 \%$ & $44 \%$ & $82 \%$ & $137 \%$ & $53 \%$ & $17 \%$ & $-16 \%$ & $11 \%$ & $52 \%$ & $66 \%$ \\
\hline $\begin{array}{l}\text { Outras/ } \\
\text { variação PII }\end{array}$ & s.v. & $31 \%$ & $-54 \%$ & $-128 \%$ & $-210 \%$ & $-79 \%$ & $-18 \%$ & $5 \%$ & $-3 \%$ & $10 \%$ & $-46 \%$ \\
\hline TC/variação PII & s.v. & $-22 \%$ & $-10 \%$ & $-47 \%$ & $-74 \%$ & $-26 \%$ & $-1 \%$ & $-11 \%$ & $8 \%$ & $62 \%$ & $21 \%$ \\
\hline GDN/variação PII & s.v. & $122 \%$ & $110 \%$ & $147 \%$ & $174 \%$ & $126 \%$ & $101 \%$ & $111 \%$ & $92 \%$ & $38 \%$ & $79 \%$ \\
\hline PII/PIB & $-47,8 \%$ & $-45,7 \%$ & $-49,2 \%$ & $-44,8 \%$ & $-35,9 \%$ & $-33,9 \%$ & $-39,6 \%$ & $-17,2 \%$ & $-37,6 \%$ & $-32,4 \%$ & s.v. \\
\hline $\begin{array}{l}\text { Transações } \\
\text { Correntes/PIB }\end{array}$ & $-4,2 \%$ & $-1,5 \%$ & $0,8 \%$ & $1,8 \%$ & $1,6 \%$ & $1,3 \%$ & $0,1 \%$ & $-1,7 \%$ & $-1,5 \%$ & $-2,3 \%$ & s.v. \\
\hline Rendas/PIB & $-3,6 \%$ & $-3,6 \%$ & $-3,4 \%$ & $-3,1 \%$ & $-2,9 \%$ & $-2,5 \%$ & $-2,1 \%$ & $-2,5 \%$ & $-2,1 \%$ & $-1,9 \%$ & s.v. \\
\hline
\end{tabular}

Fonte: Banco Central; elaboração própria.

Notas: $(1)$ TC = Transações Correntes; $P I I=$ Posição Internacional de Investimentos; variação PII = variação anual da PII; GDN = ganho de detenção nominal; $P I B$ = Produto Interno Bruto; Período = somatório ao longo do período 2001-2010; (2) valor das Transações Correntes ao longo do ano; (3) valor da Posição Internacional de Investimentos em 31 de dezembro de cada ano.

Nesse sentido e analisando-se a evolução do saldo da PII anual, observa-se como a identidade (2) apresentada neste trabalho $\left(\triangle P E L 1_{t}=-S T C_{t}\right)$ é insuficiente para explicar as mudanças ocorridas no saldo do passivo externo líquido, fazendo com que as variações "V", representadas pelo efeito GDN, constituam a variável mais importante na explicação dos resultados. Outra evidência eloquente é que o déficit acumulado em transações correntes na década em questão foi de US\$ 86 bilhões, enquanto a variação da PII foi de US\$ -412 bilhões. ${ }^{24}$

Portanto, deduz-se que a dinâmica de evolução dos estoques externos passa a depender cada vez mais das mudanças dos preços dos estoques,

24 Pela Tabela 4, observa-se que 79\% da variação do saldo da PII durante o período 20012010 foi causada pelo efeito GDN. Além disso, na análise anual, o efeito GDN explica na maioria das vezes mais de $100 \%$ da evolução da PII, enquanto os saldos em transações correntes vão geralmente no sentido contrário do saldo da PII. 
no sentido de que essa variação de valor adquire certa autonomia em relação aos saldos das transações correntes, já que o efeito GDN passa a ser o principal determinante dessa evolução. Tal processo é gerado por dois fatores principais: a) pelas variações cambiais dentro de um contexto de descasamento de moedas entre os passivos e os ativos externos; ${ }^{25}$ b) por uma dinâmica na qual a valorização do capital fica crescentemente relacionada com a variação de preço dos ativos (não por acaso, com recorrentes formações de bolhas de ativos) - no arcabouço de Keynes (2009), os agentes estão cada vez mais preocupados com o "a" da equação " $q-c+1+a$ " ${ }^{26}$

De forma preliminar, a possibilidade de aumentar o passivo externo líquido mesmo com um equilíbrio em transações correntes, decorrente de variações de preços dos estoques, enseja a hipótese de que a vulnerabilidade-estoque teria aumentado desmesuradamente. Contudo, não se deve esquecer de que o caráter "fictício" dos ativos se manifesta nas crises, portanto, justamente no momento em que a vulnerabilidade-estoque iria se manifestar, os estoques externos podem diminuir de valor consideravelmente.

Dessa maneira, vale destacar a forma como o governo brasileiro respondeu à crise internacional eclodida em 2008, com uma postura muito diferente das crises internacionais anteriores, uma vez que se adotaram medidas monetárias e fiscais anticíclicas. $O$ setor externo brasileiro se recuperou com relativa rapidez, e a capacidade demonstrada pelo país em absorver os impactos da crise internacional melhorou a percepção dos mercados em relação ao país (Barbosa; Souza, 2010).

A hipótese do presente artigo é que o governo brasileiro só pôde atuar dessa forma por conta da diminuição da vulnerabilidade-estoque de sua economia decorrente da composição da PII, preponderantemente formada por passivos externos denominados em real e do grande volume de reservas acumuladas. Isso fica evidente, como visto na Tabela 4, pela expressiva diminuição da PII brasileira de 2007 para 2008. Tal efeito, de acordo com a metodologia aqui utilizada, foi em $110 \%$ decorrente do efeito GDN, ou seja, durante a crise a variação de preços dos estoques externos se mostrou

25 Não custa lembrar que a taxa de câmbio brasileira apresenta, desde a adoção do regime de câmbio flutuante, em 1999, volatilidade bastante elevada.

26 De acordo com Keynes (2009), os agentes escolhem os ativos de acordo com sua rentabilidade esperada, levando-se em conta quatro atributos: "q", relativo à "quase-renda" do ativo; "c", que indica o custo de carregamento do ativo; "l", que representa um prêmio de liquidez que alguns ativos possuem, especialmente a moeda; e "a", que é a percentagem de valorização esperada do valor de determinado ativo. 
benéfica para o país, arrefecendo a demanda por divisas. Adicionalmente, vale apontar, de acordo com a Tabela 4, para uma tendência de queda na relação entre a PII e o PIB, passando de -48\% em 2001 para -32\% em 2010.

Já em relação à vulnerabilidade-fluxo, um dos objetivos da metodologia apresentada na Tabela 4 é tentar inferir qual a participação das rendas líquidas enviadas ao exterior no aumento do estoque do passivo externo líquido. Dessa maneira, as Transações Correntes foram desagregadas em dois grupos: a) Rendas; b) Outras. ${ }^{27}$ A tentativa de inferir qual a participação das rendas enviadas no aumento do estoque do passivo externo líquido é obtida pela relação Rendas/Variação anual da PII (pela Tabela 4: rendas/variação PII).

Dessa maneira, pela Tabela 4, observa-se como as rendas líquidas enviadas representaram aproximadamente $66 \%$ da variação do saldo da PII brasileira ao longo do período 2001-2010, evidenciando a nociva interação entre os fluxos e os estoques. Contudo, a economia apresentou uma transferência de recursos ao exterior positiva, já que o país registrou um superávit nas transações de bens e serviços de aproximadamente US\$ 188 bilhões ao longo da década, mas que foi insuficiente para fazer frente às rendas líquidas enviadas ao exterior, que atingiram a expressiva marca de US $\$ 273$ bilhões durante o período. ${ }^{28}$ Assim, pode-se considerar que a economia teve um efeito despoupança causado pelas remessas de rendas e permaneceu com uma vulnerabilidade-fluxo em potencial, mas que a relação entre as rendas e o PIB diminuiu ao longo da década (Tabela 4).

\section{Considerações finais}

Este artigo teve como objetivo investigar a vulnerabilidade externa da economia brasileira na primeira década dos anos 2000. As análises sobre o tema são geralmente focadas no comércio exterior, e, procurando contribuir com o debate, o presente estudo focou-se na esfera financeira, analisando a forma pela qual a vulnerabilidade externa é influenciada pela

27 Esse grupo representa a soma da balança comercial, de serviços e transferências unilaterais. 28 Portanto, o grande excedente em bens reais mandados para fora do país não foi suficiente sequer para pagar as rendas provenientes dos estoques externos, contudo, serviu para amenizar o aumento do passivo externo líquido (representando, de acordo com a tabela, $-46 \%$ dessa variação). Assim, os saldos em transações correntes ao longo do período explicaram apenas $21 \%$ da variação da PII (Tabela 4). 
magnitude e composição dos diversos ativos e passivos que compõem a Posição Internacional de Investimentos (PII) e pela interação entre os estoques externos e as rendas enviadas/recebidas do exterior.

No contexto de crescente financeirização das transações externas e de progressiva abertura da conta financeira brasileira, notou-se o aumento da participação dos investimentos estrangeiros em carteira e de investimentos diretos na economia brasileira, representando, de acordo com este artigo, um efeito contraditório sobre a vulnerabilidade externa do país. Por um lado, observou-se um aumento do passivo externo líquido em grande medida descolado das transações externas, visto que o déficit acumulado em transações correntes no período analisado foi de US\$ 85 bilhões, enquanto a variação da PII foi de expressivos US\$ -412 bilhões. Assim, o efeito GDN (ganhos de detenção nominal), marcado pelas variações de preços dos estoques externos, foi a variável determinante da evolução do saldo da PII.

Por outro lado, aponta-se que essas variações de valor dos estoques externos estão relacionadas com uma mudança na composição da PII brasileira, que diminuiu a participação dos passivos externos denominada em moeda estrangeira e aumentou aquela denominada em moeda doméstica, que tende a sofrer dupla valorização (câmbio e preço) em momentos de crise. Além disso, ocorreu grande aumento do ativo externo em moeda estrangeira (reservas internacionais), resultando em uma dívida externa líquida negativa. Logo, concluiu-se pela diminuição da vulnerabilidade-estoque da economia brasileira no decurso da primeira década dos anos 2000.

No que diz respeito aos fluxos, observou-se que as rendas líquidas enviadas ao exterior representaram aproximadamente dois terços da variação da PII brasileira ao longo do período 2001-2010, revelando a nefasta circularidade entre fluxos e estoques externos. Contudo, o superávit nas transações de bens e serviços serviu para amenizar o aumento do passivo externo líquido (representando $-46 \%$ dessa variação). Dessa maneira, persistindo essa situação, o país só consegue um equilíbrio nas transações correntes se realizar expressiva transferência de recursos ao exterior para o pagamento das rendas. Ao mesmo tempo, pode-se concluir que, no contexto de maior mobilidade dos capitais e de hierarquia monetária, tal situação só tende a se agravar, já que a rentabilidade do ativo externo é muito menor do que aquela do passivo externo, ou seja, formar reservas internacionais com a entrada de capitais estrangeiros tem um custo muito elevado para o país e perpetua a vulnerabilidade-fluxo. 
Dessa maneira, a inserção externa realizada pela economia brasileira pelo lado financeiro durante a primeira década do século XXI levou a uma situação de excesso de entrada de capitais estrangeiros (em relação às necessidades das transações correntes), permitindo ao mesmo tempo a grande ampliação das reservas internacionais - que tendem a melhorar a solvência externa - e a apreciação do real - que tende a piorar os déficits das transações correntes. Tal efeito contraditório sobre as contas externas parece ter levado a uma composição da PII que diminuiu a vulnerabilidade-estoque da economia brasileira, ao menos no curto prazo; mas que, no longo prazo, acentua a vulnerabilidade-fluxo e cristaliza a dependência dos financiamentos externos, principalmente para pagar as rendas desse enorme passivo externo líquido.

\section{Referências}

AGLIETTA, M. Macroéconomie financière. Paris: La Découverte, 2008.

ARAUJO, M. S. Estimativa dos Ganhos de Detenção Nominais de ativos financeiros: uma aplicação para as estatísticas de Balanço de Pagamentos e de Posição Internacional de Investimento. In: IBGE. II Encontro Nacional de Produtores e Usuários de Informações Sociais, Econômicas e Territoriais, 2006.

ARAUJO, M. S. Estatísticas do setor externo. In: FEIJÓ, C. A.; VALENTE, E.; LIMA, F. C. G. C.; CARVALHO, P. G. M. Para entender a conjuntura econômica. Barueri: Manoele, 2008.

BANCO CENTRAL DO BRASIL. Disponível em: <www.bcb.gov.br>. Acesso em: 02 de agosto de 2013

BARBOSA; SOUZA. A inflexão do governo Lula: Política econômica, crescimento e distribuição de renda. In: SADER, E.; GARCIA, M. A. Brasil, entre o passado e o futuro. São Paulo, Ed. Fundação Perseu Abramo, Boitempo, 2010.

BELLUZZO, L. G. M. As transformações da economia capitalista no pós-guerra e a origem dos desequilíbrios globais. In: CARNEIRO, R. (Org.). A supremacia dos mercados e a política econômica do governo Lula. São Paulo: Editora UNESP, 2006.

BIANCARELLI, A. Integração, ciclos e finanças domésticas: O Brasil na globalização financeira. 2007. Tese (Doutorado em Teoria Econômica) - IE/Unicamp, 2007.

BIANCARELLI, A. A abertura financeira no Brasil: Um balanço crítico. In: CARNEIRO, R.; MARCOLINO, L. C. Sistema financeiro e desenvolvimento no Brasil: Do Plano Real à crise financeira. São Paulo: Publisher Brasil e Editora Gráfica Atitude, 2010.

BIANCARELLI, A. Riscos na travessia? O financiamento externo e os desafios futuros da economia brasileira. In: CARNEIRO, R.; MATISJACIC, M. Desafios do desenvolvimento brasileiro. Brasília, IPEA, 2011.

BIANCARELLI, A. Uma nova realidade do setor externo brasileiro, em meio à crise interna- 
cional. Rede desenvolvimentista, Texto para Discussão n 13, 2012.

CARNEIRO, R. Desenvolvimento em crise: A economia brasileira no último quarto do século XX. São Paulo; Editora Unesp, IE-UNICAMP, 2002.

CARNEIRO, R. Globalização e inconversibilidade monetária. Revista de Economia Política, v. 28 , n. 4, p. 539-556, 2008.

CHESNAIS, F. O capital portador de juros: Acumulação, internacionalização, efeitos econômicos e políticos. In: CHESNAIS, F. (Org.). A finança mundializada. São Paulo: Boitempo Editorial, 2005.

CYSNE, R. P. Passivo externo líquido versus dívida externa líquida, 2008. Disponível em: <http:// www.fgv.br/professor/rubens/HOMEPAGE/ARTIGOS_E_REPORTAGENS_DE_POL_ ECON/Artigos_Publicados/2008/Passivo\%20Externo.pdf>. Acesso em: 16 abr. 2009.

DE CONTI, B. M. Políticas monetária e cambial: Os dilemas enfrentados por países emissores de moedas periféricas. 2011. Tese (Doutorado em Teoria Econômica) - IE/Unicamp e Université Paris 13, 2011.

DUMÉNIL, G.; LÉVY, D. O neoliberalismo sob a hegemonia norte-americana. In: CHESNAIS, F. (Org.). A finança mundializada. São Paulo: Boitempo Editorial, 2005.

FMI. Manual de Balanço de Pagamentos do Fundo Monetário Internacional. $5^{a}$ ed., 1993.

FMI. Quadro de Avaliação da Qualidade dos Dados das Estatísticas da Dívida Externa. Departamento de Estatística, jul. 2003.

GARCIA, M. G. P. Vulnerabilidae externa e deficiência de poupança interna. 2001. Disponível em: <http://www.econ.puc-rio.br/mgarcia/Artigos/Artigos\%20Valor/vulnerabilidade. PDF>. Acesso em: 02 de agosto de 2013.

GONÇALVES, R. Capítulo V. In: GONÇALVES, R.; PRADO, L. C. D.; BAUMANN, R.; CANUTO, O. A Nova Economia Internacional: Uma Perspectiva Brasileira. São Paulo: Ed. Campus, 1998.

GONÇALVES, R. Maxidesvalorização, vulnerabilidade externa e a crise brasileira. Revista Ensaios FEE, Porto Alegre (RS), v. 27, n. 1, p. 50-69, 1999.

GONÇALVES, R. Economia Política Internacional: Fundamentos teóricos e as relações internacionais do Brasil. Rio de Janeiro: Elsevier, 2005.

GREMAUD, A. P.; VASCONCELLOS, M. A. S.; TONEDO JÚNIOR, R. Economia brasileira contemporânea. São Paulo: Atlas, 2009.

GUTTMANN, R. Uma introdução ao capitalismo dirigido pelas finanças. Novos estudos, CEBRAP, n. 82, 2008.

KEYNES, J. M. A Teoria Geral do Emprego, do Juro e da Moeda. São Paulo: Atlas, 2009.

LACERDA, A. C. Globalização e investimento estrangeiro no Brasil. São Paulo: Saraiva, 2004.

MACEDO E SILVA, A.C.; DOS SANTOS, C.H. Além do curto prazo? Explorando os nexos entre a teoria pós keynesiana e a macrodinâmica de fluxos e estoques. Texto para Discussão. IE/ UNICAMP n. 141, abr. 2008.

OREIRO, J. L.; de PAULA, L. F.; da SILVA, G. J. C. Fluxos e controle de capitais no Brasil. In: SICSÚ, J.; OREIRO, J. L.; PAULA, L. F. (Org.). Agenda Brasil: Políticas econômicas para o crescimento com estabilidade de preços. São Paulo: Manole, 2003. 
PRATES, D. M. Crises financeiras nos países "emergentes": Uma interpretação heterodoxa. 2002. Tese (Doutorado em Teoria Econômica) - IE/Unicamp, 2002.

PRATES, D. M.; CUNHA, A. M. Controles de capitais e o perfil do passivo externo brasileiro: Tendências recentes e perspectivas. Indicadores Econômicos FEE, v. 40, p. 71-82, 2013.

PRATES, D. M.; CUNHA, A. M.; LÉLIS, M. T. C. O Brasil e a crise financeira global: Avaliando os canais de transmissão nas contas externas. Revista de Economia Contemporânea, v. 15, p. 62-91, 2011.

RECEITA FEDERAL, 2012. Disponível em: <www.receita.fazenda.gov.br>. Acesso em: 02 de agosto de 2012.

RIBEIRO, F. J. S. P. Balanço de pagamentos e vulnerabilidade externa: Evidência recente e indicadores. In: FÓRUM NACIONAL - Sessão Especial Brasil: Estratégia de Desenvolvimento Industrial, 18-19 de setembro de 2013.

SIMONSEN, M. H. \& CYSNE, R. P. Macroeconomia, 3. ed. Rio de Janeiro: Atlas, 2007.

THIRLWALL, The balance of payments constraint as an explanation of international growth rates differences. Banca Nazionale del Lavoro Quarterly Review, v. 128, 1979.

\section{Sobre os autores}

PauloVan Noije - paulovannoije@yahoo.com.br

Professor doutor de Economia e Políticas Públicas da Unicamp/FCA, Limeira, SP.

BrunoDeConti -brunodeconti@eco.unicamp.br

Professor doutor de Economia da Unicamp, Campinas, SP.

\section{Sobre o artigo}

Recebido em 7 de outubro de 2013. Aprovado em 16 de fevereiro de 2015 